\title{
In vivo proliferation of rat vascular smooth muscle in relation to diabetes mellitus insulin-like growth factor I and insulin
}

\author{
K. E. Bornfeldt ${ }^{1}$, H.J. Arnqvist ${ }^{2}$ and L. Capron ${ }^{3}$ \\ Departments of ${ }^{1}$ Pharmacology and ${ }^{2}$ Internal Medicine, Linköping University, Faculty of Health Sciences, Linköping, Sweden and \\ ${ }^{3}$ Centre de Recherches sur les Maladies Vasculaires Périphériques, Association Claude Bernard, Hôpital Broussais, Paris, France
}

\begin{abstract}
Summary. The roles of diabetes mellitus, insulin-like growth factor I and insulin in vascular smooth muscle proliferation in vivo were studied. Proliferation was induced by endothelial injury (balloon catheterization) of rat aorta, and was measured as ${ }^{3} \mathrm{H}$-thymidine incorporation into DNA. Levels of insulin-like growth factor I mRNA and insulin-like growth factor I receptor mRNA were measured with a solution hybridization assay. The increase in DNA synthesis was most pronounced 2 days after injury in both normal and diabetic rats and declined thereafter, but DNA synthesis in aortas from diabetic rats was lower throughout the time period studied. Levels of insulin-like growth factor I mRNA and the receptor mRNA were both increased in balloon catheterized aortas, and time-course studies showed an increase in receptor mRNA prior to the increase in insulin-like growth factor I mRNA. Diabetic rats were treated with equimolar concentrations of insulin $(35 \mathrm{nmol} / \mathrm{day})$ or insulin-like growth factor I
\end{abstract}

(31 nmol/day) for 5 days. Insulin-like growth factor I increased DNA synthesis in injured aortas 2 days after injury without improving blood glucose, whereas the effect of insulin was associated with a decrease in blood glucose levels. In conclusion, vascular smooth muscle proliferation is impaired by diabetes and stimulated by insulin treatment. Insulin-like growth factor I infusion stimulates vascular smooth muscle proliferation without affecting bloo glucose, and gene expressions of insulin-like growth factor I and its receptor are increased in proliferating vascular smooth muscle, indicating that insulin-like growth factor I is involved in vascular smooth muscle proliferation in vivo.

Key words: De-endothelialization, diabetes mellitus, insulin, insulin-like growth factor I, proliferation, rat, vascular smooth muscle.
Atherosclerotic disease is a main cause of morbidity and mortality in patients with diabetes mellitus. Insulin has been suggested to have a direct role in the development of atherosclerosis by stimulating proliferation of vascular smooth muscle cells [1]. The receptors for insulin and insulin-like growth factor I (IGF-I) are homologous [2]. The fact that high insulin concentrations are required to stimulate DNA synthesis and interact with the IGF-I receptor suggests that these effects could be mediated by IGF-I receptors [3, 4]. IGF-I in nanomolar concentrations stimulates proliferation of vascular smooth muscle cells in vitro $[3,4]$, although the mitogenic effect of IGF-I alone is weak compared to the effects of platelet-derived growth factor and basic fibroblast growth factor $[5,6]$. However, the growth-promoting effects of IGF-I, and high concentrations of insulin, have been found to be additive to the effects of other growth factors [7]. Thus, IGF-I and insulin may act in concert with other growth factors to stimulate vascular smooth muscle proliferation in vivo. These considerations prompted the present study to investigate the roles of insulin and IGF-I in vascular smooth muscle proliferation in normal and diabetic rats in vivo.

\section{Materials and methods}

\section{Animals}

Male rats (300 g) of the Sprague-Dawley strain (ALAB, Stockholm, Sweden) were kept under a $12 \mathrm{~h}$ light: $12 \mathrm{~h}$ darkness cycle (light from 07.00 to 19.00 hours). Diabetes was induced by $i$. v. injection of streptozotocin $(65 \mathrm{mg} / \mathrm{kg}$ body weight) in a tail vein; control rats were injected with $0.9 \% \mathrm{NaCl}$. Diabetic rats were treated with insulin (Actrapid Human $35 \mathrm{nmol} /$ day $=5 \mathrm{U} /$ day; Novo Nordisk, Copenhagen, Denmark) or recombinant human IGF-I ( $31 \mathrm{nmol} /$ day) via osmotic minipumps for 5 days ( 3 days before de-endothelialization and 2 days after). The osmotic pumps (Alzet; Alza Corp., Palo Alto, Calif., USA) were placed subcutaneously over the thoracic spine. Normal rats and diabetic rats treated with $0.9 \% \mathrm{NaCl}$ served as controls. De-endothelialization according to the method of Capron et al. [8] was performed after a diabetes duration of 2 weeks. In short, the rats were kept under light ether anaesthesia and a deflated embolectomy catheter (Fogarty, size 2F; Baxter International Inc., Santa Ana, Calif., USA) was introduced into the aorta through the left 


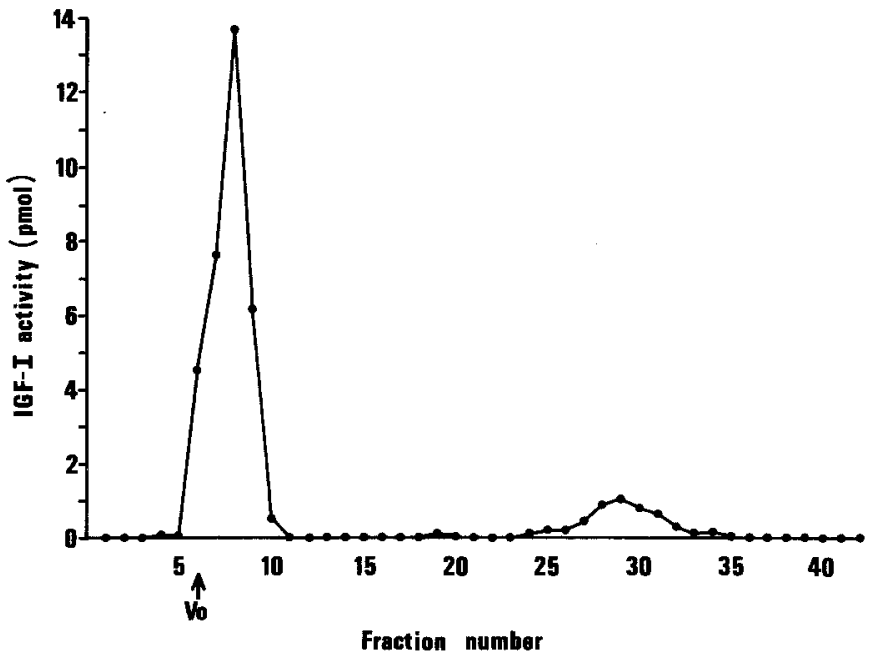

Fig. 1. Gel chromatogram of serum from an insulin-like growth factor I-(IGF-I) treated diabetic rat. Serum was diluted, and incubated in $2 \mathrm{~mol} / 1$ acetic acid for $14 \mathrm{~h}$ at $4^{\circ} \mathrm{C}$. IGF-I was separated from IGFbinding proteins on a Sephadex G-50 column in $0.1 \mathrm{~mol} / \mathrm{l}$ acetic acid. The fractions $(0.4 \mathrm{ml})$ were lyophilized, reconstituted in radioimmunoassay-buffer and analysed for IGF-I activity. IGF-binding proteins are demonstrated in fractions 6-11 and free IGF-I in fractions $25-34 . V_{o}=$ Void volume

common carotid artery down to the level of the renal arteries. The balloon was inflated with $40-50 \mu \mathrm{l}$ distilled water, and withdrawn to the level of the diaphragm where it was inflated with an additional $20-30 \mu$ l of distilled water. This procedure was repeated twice and the carotid artery was then double ligated. Selection of the rat prior to catheterization was performed randomly to avoid bias. Shamoperated control rats were treated in the same way but the catheter was not introduced into the aorta. To study re-endothelialization, rats were anaesthetized with Ketalar (Parke-Davies, Barcelona, Spain) and Rompun (Bayer AG, Leverkusen, FRG) and $2 \mathrm{ml}$ Evans blue $(0.5 \%)$ was injected into a tail vein. After 30 min the aortas were prepared, cleaned, examined and photographed. White spots were considered to represent areas covered with endothelial cells.

Body weights of the rats were measured daily at 10.00 hours, and blood glucose was measured twice daily using a hexokinase method (Gluco-quant; Boehringer-Mannheim, Mannheim, FRG).

\section{Measurements of serum insulin and IGF-I}

Serum levels of insulin and IGF-I were measured with radioimmunoassays. Since IGF-binding proteins interact with the IGF-I radioimmunoassay, serum IGF-I was separated from IGF-binding proteins according to a modified method of Philipps et al. [9]. Serum $(75 \mu \mathrm{l}$ ) was acidified and diluted to $360 \mu \mathrm{l}$ with acetic acid (final concentration $2 \mathrm{~mol} / \mathrm{l}$ ), and then incubated at $4^{\circ} \mathrm{C}$ overnight. IGF-I was separated from binding proteins on a $50 \times 1.0 \mathrm{~cm}$ Sephadex G50 (fine) column (Pharmacia Fine Chemicals, Uppsala, Sweden) equilibrated in $0.1 \mathrm{~mol} / \mathrm{l}$ acetic acid, and a flow rate of $1.5-2.0 \mathrm{~m} 1 / \mathrm{h}$. The columns were calibrated with dextran blue, cytochrome $\mathrm{C}$ $\left(\mathrm{M}_{\mathrm{r}}=12.5\right.$ kilodaltons) and ${ }^{125} \mathrm{I}-\mathrm{IGF}-\mathrm{I}$ (Amersham International plc, Amersham, Bucks, UK). The separation of the binding protein peak and the IGF-I peak on a Sephadex G50 column is illustrated in Figure 1 . Less than $5 \%$ of ${ }^{125}$ I-IGF-I pre-incubated with serum at neutral $\mathrm{pH}$ for $24 \mathrm{~h}$ was still associated with binding proteins after acidification and chromatography. Fractions containing free IGF-I were pooled and lyophilized. IGF-I was measured with radioimmunoassay as described [10], using recombinant human IGF-I as standard. The recovery when recombinant IGF-I was incubated with a serum sample, acidified, separated on columns, lyophilized and measured was $99.9 \pm 12.0 \%(n=4)$. Serum insulin was measured with Phadeseph insulin radioimmunoassay kit (Pharmacia Diagnostics, Uppsa$\mathrm{la}$, Sweden) based on a double antibody technique.

\section{Measurement of DNA synthesis}

After $0,1,2,7$ and 14 days, rats were anaesthetized with ether, the aortic segment between the left subclavian artery and the celiac artery was removed, opened longitudinally, and transferred into $2 \mathrm{ml}$ of Krebs-Henseleit bicarbonate buffer according to Capron et al. [8]. DNA synthesis in the intima-media was measured as ${ }^{3} \mathrm{H}$-thymidine incorporation during $1 \mathrm{~h}$ incubation, and DNA was purified from proteins and RNA according to Hutchison and Munro [11].

\section{Measurement of IGF-ImRNA and IGF-I receptor $m R N A$}

Levels of IGF-I mRNA and IGF-I receptor mRNA were measured in the intima-media from normal rats. The rats were killed by an overdose of ether, the aorta dissected into the intima-media and adventitia layers and the intima-media layer was frozen in liquid nitrogen. Intima-medias from two normal rats were pooled in each sample. The intima-medias were homogenized in a sodium-dodecyl sulphate-containing buffer with a glass-glass homogenizer for approximately $30 \mathrm{~s}$. The samples were digested with proteinase K (Merck, Darmstadt, FRG) and then extracted with phenol and chloroform. Total nucleic acid (TNA) was precipitated by addition of ethanol, and DNA content was measured by fluorimetry [12]. Levels of IGF-I mRNA were analysed using a ${ }^{35} \mathrm{~S}$-UTP labelled RNA probe complementary to 153 base pairs in exon 3 of the mouse IGF-I gene [13], and a 265 bases rat IGF-I receptor RNA probe complementary to part of the 5'untranslated sequence and sequences encoding the signal peptide and the first 53 amino acids of the IGF-I receptor $\alpha$-subunit [14] was used to measure IGF-I receptor mRNA. Solution hybridization was performed as described previously [15]. In short, the probes were hybridized to TNA samples at $70^{\circ} \mathrm{C}$ for $16 \mathrm{~h}$. The samples was then exposed to RNases and the hybrids subsequently precipitated with trichloroacetic acid and collected on glass-microfibre filters. The radioactivity of the samples was measured in a liquid scintillation counter and compared with that of a standard curve constructed from incubation with a rat liver TNA sample with a known amount of IGF-I mRNA or a synthetic standard of IGF-I receptor mRNA.

\section{Statistical analysis}

Values are given as mean \pm SEM. Levels of significance were calculated by using analysis of variance.

\section{Results}

\section{Time course of DNA synthesis}

The time courses of ${ }^{3} \mathrm{H}$-thymidine incorporation into DNA (estimated as DNA specific activity, cpm/ $\mathrm{\mu g}$ DNA) in normal and diabetic rats were similar as shown in Figure 2. A peak in DNA synthesis was seen 2 days after injury, and a decline was evident between day 2 and day 7. However, the DNA synthesis in aortas from diabetic rats was lower than in aortas from normal rats throughout the time period studied. DNA specific activity in sham-operated animals was similar day 0 and day 14, but sham-operated diabetic rats had a lower specific activity than normal rats (Fig. 2).

The DNA content 2 weeks after injury was $85.4 \pm 4.0 \mu \mathrm{g}$ DNA/aorta $(n=4)$ in normal rats and $59.2 \pm 1.7 \mu \mathrm{g}$ DNA/aorta in diabetic rats $(n=4 ; p \leq 0.001$ when analysed with two-tailed Student's $t$-test for unpaired observations). The DNA content in sham-operated control rats was $62.8 \pm 2.1 \mu \mathrm{g}$ DNA/aorta $(n=3)$ 2 weeks after sham-operation. 


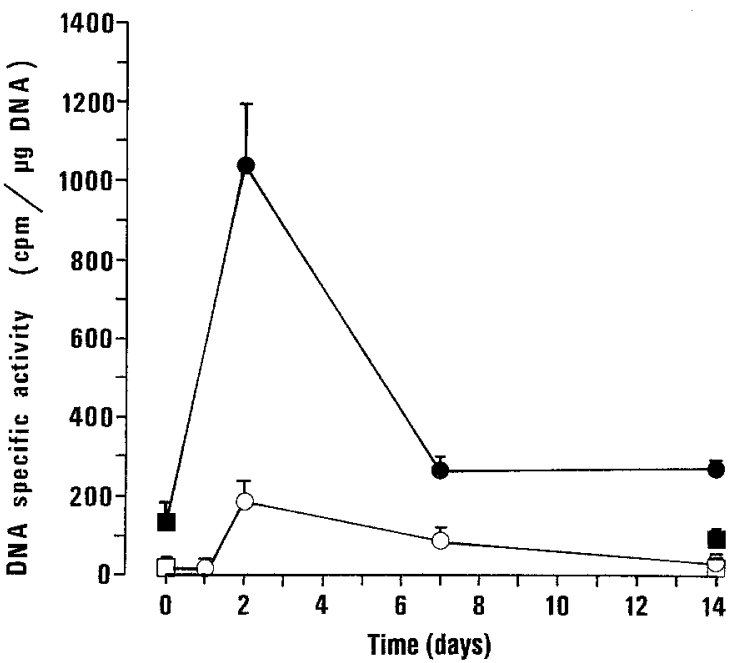

Fig. 2. Time-course studies of DNA synthesis in intima-media after balloon catheterization of normal rats $(0)$ and diabetic rats $(0)$. Balloon catheterization was performed on day 0 . Sham-operated rats are marked with squares $(\square, \boldsymbol{\square})$. Values are presented as mean \pm SEM (injured rats, $n=4$; sham-operated normal rats day 14 , $n=3$; sham-operated diabetic rats and normal rats day $0, n=2$ )
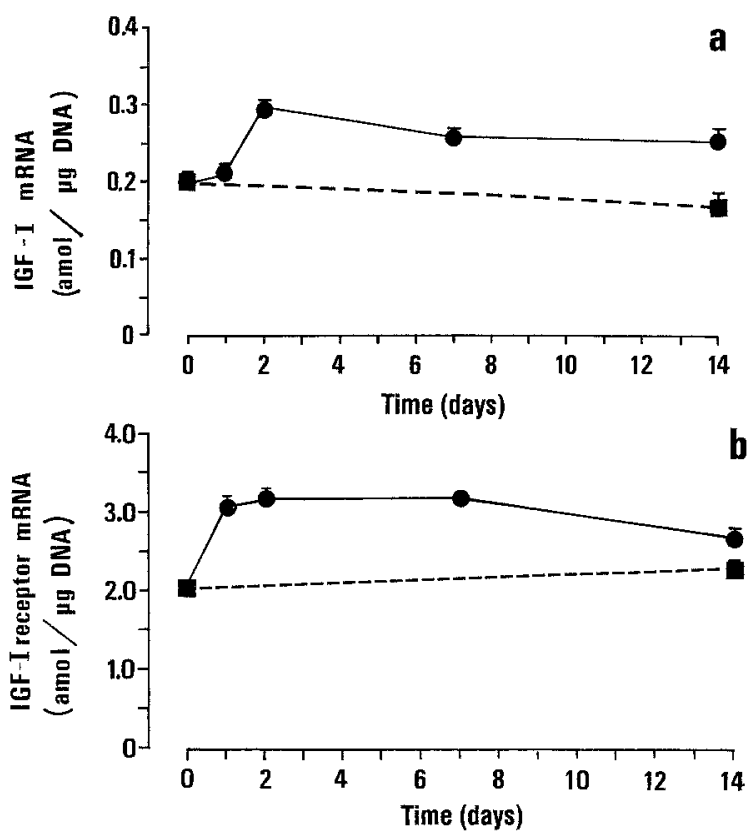

Fig.3a,b. Time-course studies of levels of insulin-like growth factor I (IGF-I) mRNA (a) and IGF-I receptor mRNA (b) in intima-media after balloon catheterization of normal rats $(\bullet)$. Balloon catheterization was performed on day 0 . Sham-operated rats are marked with squares ( $\mathbf{m})$. Values are presented as mean a $\left(1 \times 10^{-18}\right) \mathrm{mol}$ $\mathrm{mRNA} / \mu \mathrm{g}$ DNA $\pm \mathrm{SEM}$ (injured rats, $n=4$; sham-operated normal rats day $14, n=3$; sham-operated normal rats day $0, n=2$ )

\section{Evans blue staining}

Two days after injury the balloon catheterized aortas were completely blue when compared with aortas from sham-operated rats. Seven days after the injury, white spots, representing re-endothelialized areas, had appeared around the intercostal arteries, and 2 weeks after the injury more than half of the aorta was re-endothelialized (data not shown). No differences between nondiabetic and diabetic rats were found either in shamoperated rats, or 2, 7 or 14 days after endothelial injury (data not shown).

\section{Time course of IGF-ImRNA and IGF-I receptor $m R N A$}

Levels of IGF-I mRNA in intima-media from normal rats were increased $49.2 \pm 0.1 \% 2$ days after injury, and the time course of the increase was associated with increase in DNA synthesis (Fig. 3 a). The levels of IGF-I mRNA in shamtreated rats were similar before the operation and 14 days after the operation (Fig. 3 a). Levels of IGF-I receptor mRNA were increased at an earlier time-point after injury compared with IGF-I mRNA ( $52.2 \pm 7.6 \%$ increase 1 day after injury), and declined 14 days after injury (Fig. 3 b).

\section{Effect of insulin and IGF-I on DNA synthesis in diabetic rats}

Treatment of diabetic rats with insulin ( $35 \mathrm{nmol} /$ day) or IGF-I ( $31 \mathrm{nmol} /$ day) during 5 days increased body weights $33 \pm 2 \mathrm{~g}$ (from $252 \pm 7 \mathrm{~g}$ ) and $18 \pm 3 \mathrm{~g}$ (from $245 \pm 9 \mathrm{~g}$ ), respectively. Body weights of diabetic rats treated with $0.9 \% \mathrm{NaCl}$ were unchanged $(3 \pm 1 \mathrm{~g}$, from $244 \pm 7 \mathrm{~g}$ ), whereas the non-diabetic rats increased $11 \pm 2 \mathrm{~g}$ (from $321 \pm 4 \mathrm{~g}$ ) during the 5-day period. Insulin decreased, but did not normalize, blood glucose levels $(32.6 \pm 1.2$ to $19.9 \pm 1.7 \mathrm{mmol} / \mathrm{l})$, whereas IGF-I did not affect blood glucose levels of the diabetic rats at all $(31.3 \pm 1.0$ to $30.4 \pm 1.6 \mathrm{mmol} / \mathrm{l})$. Blood glucose of normal rats was $7.1 \pm 0.1 \mathrm{mmol} / 1$ at the end of the treatment period. Serum levels of insulin and IGF-I are shown in Table 1.

Both insulin and IGF-I increased DNA synthesis in injured aortas from diabetic rats (Fig. 4), but DNA synthesis did not reach the level found in normal rats.

Table 1. Effects of different treatments on serum levels of insulin and insulin-like growth factor I (IGF-I) in balloon catheterized rats. Serum insulin was measured with Phadeseph insulin radioimmunoassay kit (Pharmacia). To measure serum IGF-I, serum was diluted and incubated in $2 \mathrm{~mol} / \mathrm{l}$ acetic acid for $14 \mathrm{~h}$ at $4^{\circ} \mathrm{C}$. IGF-I was separated from IGF-binding proteins on Sephadex G-50 columns in $0.1 \mathrm{~mol} / 1$ acetic acid. The fractions containing free IGF-I were pooled, lyophilized, reconstituted in radioimmunoassay-buffer and analysed for detectable IGF-I

\begin{tabular}{lccc}
\hline Treatment & & Insulin (pmol/l) & IGF-I (nmol/l) \\
\hline $\begin{array}{l}\text { Control } \\
\text { Diabetic }\end{array}$ & $(4)$ & $113 \pm 9$ & $60.9 \pm 3.5$ \\
untreated & $(7)$ & $78 \pm 14$ & $28.5 \pm 3.2$ \\
$\begin{array}{l}\text { Diabetic } \\
\text { insulin-treated }\end{array}$ & $(7)$ & $623 \pm 107$ & $53.6 \pm 3.7$ \\
$\begin{array}{l}\text { Diabetic } \\
\text { IGF-I-treated }\end{array}$ & $(5)$ & $58 \pm 9$ & $104.3 \pm 8.4$ \\
\hline
\end{tabular}

Values are presented as mean \pm SEM (number of observations are given within parentheses) 


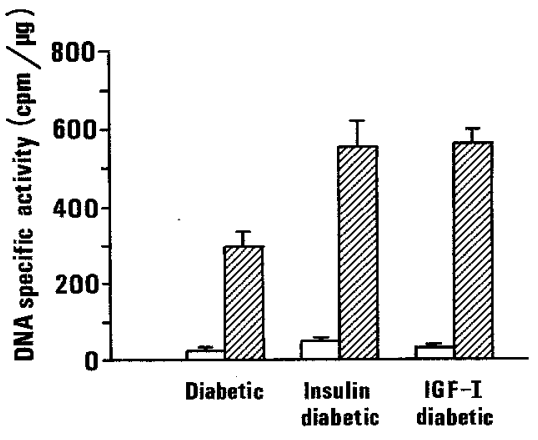

Fig. 4. DNA synthesis in intima-media 2 days after endothelial injury ( $\square)$ in untreated diabetic rats $(n=7)$, diabetic rats treated with $35 \mathrm{nmol}$ insulin/day $(n=7)$ and diabetic rats treated with $31 \mathrm{nmol}$ insulin-like growth factor-I (IGF-I)/day $(n=5)$. Open bars $(\square)$ indicate sham-operated rats (untreated diabetic rats and insulin-treated diabetic rats, $n=4$, IGF-I-treated diabetic rats, $n=3$ ). Values are presented as mean \pm SEM. DNA-specific activity was $939 \pm 46 \mathrm{cpm} / \mu \mathrm{g}$ DNA in injured aortas from normal rats and $225 \pm 48 \mathrm{cpm} / \mu \mathrm{g}$ DNA in sham-operated normal rats $(n=4)$. The $p$ value was less than 0.001 when injured insulin-treated diabetic rats and injured untreated diabetic rats were compared, as well as when injured IGF-I-treated diabetic rats and injured-untreated diabetic rats were compared using analysis of variance

\section{Discussion}

The results of the present study show that DNA synthesis after endothelial injury is impaired by diabetes. In previous studies addressing this issue, no difference in DNA synthesis [8] or the size of the intimal lesions [16] after endothelial injury was found when diabetic and non-diabetic rats were compared. The contradictory results may be due to the use of a different strain of rats in these studies (Wistar rats), or the different duration of diabetes. Another explanation may be that the severity of the diabetic state is important for vascular smooth muscle proliferation in diabetic rats, since both of the previous studies used lower doses of streptozotocin ( $40-45 \mathrm{mg} / \mathrm{kg}$ body weight) than that used in the present study ( $65 \mathrm{mg} / \mathrm{kg}$ body weight). Recently, it was reported that fasting decreases DNA synthesis after endothelial injury [17]. Fasting, like diabetes, is characterized by low levels of insulin and IGF-I, and the mechanisms responsible for the decreased DNA synthesis during fasting and severe diabetes may be similar.

Treatment of diabetic rats with insulin for 5 days lowered blood glucose, improved the diabetic state and increased DNA synthesis. These effects of insulin indicate that the impaired DNA synthesis during untreated diabetes is due the diabetic state per se and not to a toxic effect of streptozotocin. Although the diabetic rats treated with insulin were clearly hyperinsulinaemic at the end of the experiment, DNA synthesis was not increased to the level found in non-diabetic rats. It may be speculated that the effect of insulin on DNA synthesis is not direct, but due to general improvement of the diabetic state. Part of the effect of insulin may be mediated by IGF-I since insulin infusion normalized serum levels of IGF-I. IGF-I increased DNA synthesis without affecting blood glucose levels. The effect of IGF-I is probably due to stimulation of IGF-I receptors in vascular smooth muscle, and a direct effect of IGF-I on DNA synthesis has previously been shown in cultured vascular smooth muscle cells $[3,4]$. However, it can not be excluded that IGF-I is also important for metabolism in the vascular wall. Several metabolic parameters [18], and levels of IGF-I mRNA are markedly decreased in rat aorta by diabetes and fasting [15]. Both metabolic states obviously can result in an impaired proliferation of the vascular smooth muscle cells.

Infused IGF-I has recently been found to increase DNA synthesis in thymocytes from diabetic rats despite persisting hyperglycaemia [19], which indicates that circulating IGF-I is able to increase proliferation in various tissues in vivo. The results of the present study show that levels of IGF-I receptor mRNA may be increased before the well-documented increase in DNA synthesis after endothelial injury $[8,20]$. An increased expression of IGF-I receptors should result in an enhanced effect of circulating, but also locally produced, IGF-I on the vascular smooth muscle cells, and increased IGF-I immunoreactivity has previously been demonstrated in the vascular wall after endothelial injury [21]. The increased levels of IGF-I mRNA in vascular smooth muscle after endothelial injury demonstrated in the present study, and in a recent study [22], indicate that IGF-I may also have autocrine effects during vascular smooth muscle proliferation in vivo.

In conclusion, IGF-I is involved in proliferation of vascular smooth muscle in vivo.

Acknowledgements. We are grateful to Mrs. R. Gidlöf for providing excellent technical assistance during part of this work, to Dr. A.Skottner, Kabi Pharmacia Peptide Hormones, Stockholm, Sweden for kindly supplying the recombinant IGF-I, to Dr. G. Norstedt for the IGF-I RNA probe and to Dr. D. LeRoith for the IGF-I receptor probe. The study was supported by grants from the Swedish Medical Research Council (4952), the Swedish Hoechst Diabetes Fund, the Swedish Diabetes Association, Nordisk Insulinfond and the Swedish Society for Medical Research.

\section{References}

1. Stout RW (1990) Insulin and atheroma. 20-Yr perspective. Diab Care 13: 631-654

2. Ullich A, Gray A, Tam AW et al. (1986) Insulin-like growth factor I receptor primary structure: comparison with insulin receptor suggests structural determinants that define functional specificity. EMBO J 5: 2503-2512

3. King GL, Goodman AD, Buzney S, Moses A, Kahn CR (1985) Receptors and growth-promoting effects of insulin and insulinlike growth factors on cells from bovine retinal capillaries and aorta. J Clin Invest 75:1028-1036

4. Bornfeldt KE, Gidlöf RA, Wasteson Å, Lake M, Skottner A, Arnqvist HJ (1991) Binding and biological effects of insulin, insulin analogues and insulin-like growth factors in rat aortic smooth muscle cells. Comparison of maximal growth promoting activities. Diabetologia 34: 307-313

5. Cascieri MA, Chicchi GG, Hayes NS, Slater EE (1986) Stimulation of DNA synthesis in rat A 10 vascular smooth muscle cells by threonine-59 insulin-like growth factor-I. Circ Res 59: 171-177

6. Bornfeldt KE, Arnqvist HJ, Norstedt G (1990) Regulation of insulin-like growth factor-I gene expression by growth factors in cultured vascular smooth muscle cells. J Endocrinol 125:381-386

7. Clemmons DR (1984) Interaction of circulating cell-derived and plasma growth factors in stimulating cultured smooth muscle cell replication. J Cell Physiol 121: 425-430 
8. Capron L, Jarnet J, Kazandjian S, Housset E (1986) Growth-promoting effects of diabetes and insulin on arteries. An in vivo study of rat aorta. Diabetes 35:973-978

9. Philipps A, Drakenberg K, Persson B et al. (1989) The effects of altered nutritional status upon insulin-like growth factors and their binding proteins in neonatal rats. Pediatr Res 26: 128-134

10. Skottner A (1988) Human growth hormone variants and insulinlike growth factor I: effects on growth parameters and peripheral nerve regeneration in rats. Uppsala University Thesis. Reklam and Katalogtryck, Uppsala

11. Hutchison WC, Munro HN (1961) The determination of nucleic acids in biological materials. Analyst 86: 768-813

12. Labarca C, Paigen K (1980) A simple, rapid and sensitive DNA assay procedure. Anal Biochem 102: 344-352

13. Mathews LS, Norstedt G, Palmiter RD (1986) Regulation of insulin-like growth factor I gene expression by growth hormone. Proc Natl Acad Sci USA 83: 9343-9347

14. Werner H, Woloschak M, Adamo M, Shen-Orr Z, Roberts CT Jr, LeRoith D (1989) Developmental regulation of the rat insulinlike growth factor I receptor gene. Proc Natl Acad Sci USA 86: $7451-7455$

15. Bornfeldt KE, Arnqvist HJ, Enberg B, Mathews LS, Norstedt G (1989) Regulation of insulin-like growth factor-I and growth hormone receptor gene expression by diabetes and nutritional state in rat tissues. J Endocrinol 122: 651-656

16. Haudenschild CC, Van Sickle W, Chobanian AV (1981) Response of the aorta of the obese Zucker rat to injury. Arteriosclerosis 1: 186-191

17. Ridray S, Capron L, Heudes D, Picon L, Ktorza A (1991) Effects of fasting and refeeding on the proliferative response of rat aorta to injury. Am J Physiol 261: H190-H195
18. Dahlkvist HH, Arnqvist HJ, Norrby K (1981) Influence of diabetes on oxidation of exogenous substrates in rat aorta. Diab \& Metab 7:275-281

19. Binz K, Joller P, Froesch P, Binz H, Zapf J, Froesch ER (1990) Repopulation of the atrophied thymus in diabetic rats by insulinlike growth factor I. Proc Natl Acad Sci USA 87: 3690-3694

20. Goldberg ID, Stemerman MB, Schnipper LE, Ransil BJ, Crooks GW, Fuhro RL (1979) Vascular smooth muscle kinetics: a new assay for studying patterns of cellular proliferation in vivo. Science 205: 920-922

21. Hansson H-A, Jennische E, Skottner A (1987) Regenerating endothelial cells express insulin-like growth factor-I immunoreactivity after arterial injury. Cell Tissue Res 250: 499-505

22. Cercek B, Fishbein MC, Forrester JS, Helfant RH, Fagin JA (1990) Induction of insulin-like growth factor I messenger RNA in rat aorta after balloon denudation. Circ Res 66: 1755-1760

Received: 1 August 1991

and in revised form: 11 October 1991

Dr. K.E.Bornfeldt

Department of Pharmacology

Faculty of Health Sciences

Linköping University

S-58185 Linköping

Sweden 